\title{
CONTENT OF CHEMICAL ELEMENTS IN WOOD-DESTROYING FUNGI
}

\author{
Strapáč, I. ${ }^{1}$, Baranová, M. ${ }^{2}$ \\ ${ }^{1}$ Department of Chemistry, Biochemistry and Biophysics, Institute of pharmaceutical chemistry \\ ${ }^{2}$ Department of Food Hygiene and Technology, Institute of milk hygiene and technology \\ University of Veterinary Medicine and Pharmacy, Komenského 73, 04181 Košice \\ The Slovak Republic \\ imrich.strapac@uvlf.sk
}

\section{ABSTRACT}

The aim of this study was to examine the content of chemical elements in the dried fruiting bodies of edible wood decaying fungi such as Honey mushrooms (Armillaria mellea), Shiitakes (Lentinus edodes) and Oyster mushrooms (Pleurotus ostreatus). Powdered samples of fungi were mineralized in a microwave digestion. Twenty-one (21) chemical elements were detected in the plasma of the device ICP-MS AGILENT 7500c by accredited methods with the aid of calibration curves. The content of individual elements varied within a considerable range. The highest contents of $\mathrm{K}, \mathrm{Mn}, \mathrm{Cu}$ and $\mathrm{Cd}$ were found in the fruiting bodies of Honey mushrooms (Armillaria mellea). Shiitakes (Lentinus edodes) had the highest content of B and Mo. Significant differences were found in the content of elements in the Oyster mushrooms (Pleurotus ostreatus) from Slovakia, Hungary and China. The highest content of Al was found in the Oyster mushrooms (Pleurotus ostreatus) from Hungary. The Chinese oysters had a maximum contents of $\mathrm{Ca}, \mathrm{Mg}, \mathrm{Co}$, $\mathrm{Pb}$, As and $\mathrm{U}$. The Oyster mushrooms (Pleurotus ostrea- tus) from Lemešany (Slovakia) had the highest contents of $\mathrm{Na}, \mathrm{Zn}, \mathrm{Fe}, \mathrm{Se}, \mathrm{Ag}, \mathrm{Hg}$ and $\mathrm{Cr}$. The difference of chemical element content could be influenced by the genotype of the fungus and by the composition of substrate on which mushroom grow up.

Key words: Armillaria mellea; chemical elements; ICP-MS; Lentinus edodes; Pleurotus ostreatus

\section{INTRODUCTION}

Fungi and mushrooms play an important role in ecosystems. They participate in the process of decomposition of live and dead matter, which often causes, particularly in the forest sector, considerable damage. During their short life, mushrooms in their bodies accumulate important substances for human nutrition. Cultivated mushrooms were found to be a good source of: vitamins [24, 27], dietary fibres, polysaccharides, $\alpha$ - and $\beta$-glucans which have immunostimulating, immunomodulating and anti-cancer properties [29, 30]. Mushrooms contain $\beta$-carotene, lyco- 
pene, tocopherols [24], phenolics, and flavonoids with antioxidant effects [6]. They contain a number of biologically active substances that function as enzymes, protease inhibitors, lectins and so on [15]. Edible wild grown mushrooms are relatively rich in essential trace elements such as potassium, phosphorus, selenium, iron, zinc, manganese, and copper [3], but also absorb toxic elements such as mercury, cadmium, lead, silver and arsenic from the substrate, which are hazardous in the diet $[5,8,9,10,11]$. Many studies have drawn attention to the occurrence and concentration of toxic elements found in the fruiting body of mushrooms. In order to obtain valuable biologically active substances from fungi, researchers have developed new technological methods of cultivating fungi on substrates such as straw, cereals and other agricultural raw materials [17], or fungi are grown as a tissue cultures with a strictly defined composition of the substrate [16].

The aim of this study was to examine the content of chemical elements in the dried fruiting bodies of edible wood decaying fungi such as Honey mushrooms (Armillaria mellea), Shiitakes (Lentinus edodes) and Oyster mushrooms (Pleurotus ostreatus) grown in various substrates in different countries.

\section{MATERIALS AND METHODS}

As experimental materials, we used homogeneous powder of the dried fruiting bodies of Honey mushrooms (Armillaria mellea) originating from Slovakia-mushrooms were picked up in the forest; Shiitakes (Lentinus edodes) originating from China-mushrooms were bought at the store and Oyster mushroom (Pleurotus ostreatus) originating from Hungary and China (mushrooms were also bought at the store) and originating from Slovakia (small village Lemešany) - mushrooms were cultivated on wooden blocks.

Powdered samples of fungi were mineralized in a microwave digestion with $6 \mathrm{~cm}^{3}$ of concentrated $\mathrm{HNO}_{3}$ and $1 \mathrm{~cm}^{3}$ of $30 \% \mathrm{H}_{2} \mathrm{O}_{2}$. The mineralized samples were analysed in the plasma of the device ICP-MS AGILENT 7500c (Agilent, USA) by accredited methods used at the State Veterinary and Food Institute in Košice. The contents of 21 chemical elements were detected by means of the aid of the calibration curves (Table 1). The reagents used were of the highest quality (Suprapur and p.a.). Mercury was deter- mined using a special device (AMA 254) for the determination of $\mathrm{Hg}$ directly in the powdered material without mineralization. The results are reported as the average of three measurements in mg.kg-1 DW with the corresponding SD.

\section{RESULTS AND DISCUSSION}

Mushrooms have been part of a normal human diet for thousands of years. Analysed edible wood decaying fungi such as Honey mushrooms (Armillaria mellea), Shiitakes (Lentinus edodes) and Oyster mushrooms (Pleurotus ostreatus) are valued due to their aroma and taste, as well as their proteins, dietary fibre, low fat content, vitamins, essential trace elements and a number of other biologically active substances. Fresh and preserved fruiting bodies of them can be culinary - processed in different ways. For many years, edible wood decaying fungi were widely used in traditional medicine. In recent years, much attention has focused on various immunological and anti-cancer properties of certain mushrooms that offer potentially important health benefits, including antioxidants, anti-hypertensives, cholesterol-lowering properties, and liver protection, as well as anti-inflammatory, anti-diabetic, anti-viral and anti-microbial properties [5]; [13]. These properties have attracted the interest of many pharmaceutical companies as a rich source of innovative biomedical molecules.

Mushrooms have the ability to accumulate not only toxic but also the essential chemical elements from the environment in which they grow. Therefore, mushrooms can be used as an indicator of pollution in particular in the areas of mining and metallurgical metal processing [8]; [9]; [10]; [11]. Cultivated mushrooms are characterized by a lower content of toxic elements [8].

The mean content of chemical elements is presented in the Table. 1 . The results are expressed in $\mathrm{mg} \cdot \mathrm{kg}^{-1}$ dry weight (DW).

The results of this study demonstrated that the concentrations of chemical elements in the various kinds of wood decaying fungi were different. The highest concentration of boron was measured in fruiting bodies of Shiitakes (Lentinus edodes) originating from China. The lowest content of boron was found in the fruiting bodies of Oyster mushroom (Pleurotus ostreatus) originating from Hungary. Kaya and Bag [12] found in Honey mushrooms (Armillaria mellea) a boron value of $0.243 \mathrm{mg} \cdot \mathrm{kg}^{-1}$ 
and in Rogers mushrooms (Lentinus tigrinus) the value of $1.132 \mathrm{mg} \cdot \mathrm{kg}^{-1}$. The boron content in the fruiting bodies of Oyster mushrooms (Pleurotus ostreatus) was in the range from ND (not detected) to $2.630 \mathrm{mg} \cdot \mathrm{kg}^{-1}$. In comparison with these results, the boron content in our samples of the fruiting bodies of Oyster mushrooms (Pleurotus ostreatus) varied from 0.323 to $0.563 \mathrm{mg} \cdot \mathrm{kg}^{-1}$. Vetter [25] determined higher boron content (5-15 mg. $\mathrm{kg}^{-1}$ ) in Marasmius wynnei. Kon uk [14] in compliance with our results have published $0.50 \mu \mathrm{g} . \mathrm{g}^{-1}$ boron content in Honey mushrooms (Armillaria mellea).

Extremely high levels of aluminium were found in Oyster mushrooms (Pleurotus ostreatus) originating from Hungary (14527 mg. $\mathrm{kg}^{-1}$ ). This is probably a consequence of the high aluminium content in the soil. Hungary is rich in bauxite, which is an aluminium ore. The lowest aluminium content was measured in the fruiting bodies of Shiitakes (Lentinus edodes) originating from China (69.67 mg. $\mathrm{kg}^{-1}$ ) (Table 1).

Oyster mushrooms (Pleurotus ostreatus) from different countries showed widely different results for the aluminium content. Kaya and Bag [12] reported aluminium content in 24 different mushroom species ranging from 18.71 to $1486 \mathrm{mg} \cdot \mathrm{kg}^{-1}$ DW. Other scientists have mentioned the aluminium content in different mushroom species in the range from 8.5 to $365 \mu \mathrm{g} \cdot \mathrm{g}^{-1}$ or 68 to $420 \mu \mathrm{g} . \mathrm{g}^{-1}$ (cited in Kaya and Bag [12]). Our results, except for the extreme value of aluminium found in Oyster mushrooms (Pleurotus ostreatus) originating from Hungary, are in accordance with the values of aluminium published in the literature for different varieties of mushrooms.

The high aluminium content presents a risk to human health. The WHO recommends an acceptable daily intake of aluminium of $60 \mathrm{mg}$ per day.

The sodium content was found in a range of 4.684 and $51.49 \mathrm{mg} \cdot \mathrm{kg}^{-1}$. The highest value of sodium was found in Oyster mushrooms (Pleurotus ostreatus) grown on a wooden block (Table 1). The farmer used sodium chloride to protect Oyster mushrooms against snails and this probably caused an increased sodium content in fruiting bodies.

Ayaz et al. [1] reported a high content of sodium $363.57 \pm 13.40 \mathrm{mg} \cdot \mathrm{kg}^{-1} \mathrm{DW}$ in Honey mushrooms (Armillaria mellea). Muszyńska et al. [19] reported $100 \pm 67.00$ mg. $\mathrm{kg}^{-1}$ of sodium in fruiting bodies DW of Honey mushrooms (Armillaria mellea). In comparison with the published values, our results of sodium content in mushrooms were lower.
Mushrooms are an important source of potassium. For edible wild grown mushrooms Kalač $[10,11]$ determined that the potassium content was in a range of 20000 to $40000 \mathrm{mg} \cdot \mathrm{kg}^{-1}$. Zhang et al. [31] reported the potassium content in a range of 29000 to $45000 \mathrm{mg} \cdot \mathrm{kg}^{-1}$. These values of the potassium content are extremely high in comparison with our results. Our maximum value of potassium content was $21009 \mathrm{mg} \cdot \mathrm{kg}^{-1}$. Other values of potassium content were lower and ranged from 10588 to $15684 \mathrm{mg} \cdot \mathrm{kg}^{-1}$ (Table 1).

The calcium content of $34.77 \mathrm{mg} . \mathrm{kg}^{-1}$ was found in Honey mushrooms (Armillaria mellea) and of $126.32 \mathrm{mg} \cdot \mathrm{kg}^{-1}$ in Oyster mushrooms (Pleurotus ostreatus) originating from China (Table1).

Kalač $[10,11]$ determined that the calcium content was in a range from 100 to $500 \mathrm{mg} \cdot \mathrm{kg}^{-1} \mathrm{DW}$. Zhang et al. [31] reported that the calcium content was in a range from 35 to $190 \mathrm{mg} \cdot \mathrm{kg}^{-1}$ DW. Our results of the calcium content in mushrooms corresponded with these published results.

The usual contents of magnesium in wild growing mushrooms are in a range from 650 to $1300 \mathrm{mg} \cdot \mathrm{kg}^{-1} \mathrm{DW}$. Kala č [10]; [11] determined that the magnesium content was in a range from 800 to $1800 \mathrm{mg} \cdot \mathrm{kg}^{-1} \mathrm{DW}$. Our results of the magnesium content (924.1 to $1028.1 \mathrm{mg} \cdot \mathrm{kg}^{-1} \mathrm{DW}$ ) in mushrooms were in a range of these published results (Table 1).

The highest manganese (13.49 mg.kg-1 DW) and copper (8.729 mg. kg-1 DW) contents were in Honey mushrooms (Armillaria mellea) originating from Slovakia. The highest zinc (34.17 mg.kg-1 DW) and iron (97.03 mg. $\left.\mathrm{kg}^{-1} \mathrm{DW}\right)$ contents were in Oyster mushrooms (Pleurotus ostreatus), also originating from Slovakia (Table 1).

Kalač [10] determined the usual range of manganese content (5-60 mg. $\left.\mathrm{kg}^{-1} \mathrm{DW}\right)$, copper content $\left(10-70 \mathrm{mg} \cdot \mathrm{kg}^{-1}\right.$ DW), zinc content (30-150 mg. $\left.\mathrm{kg}^{-1} \mathrm{DW}\right)$ and iron content (30-150 mg.kg-1 DW). Zhang et al. [31] determined that the manganese, copper, zinc and iron contents were in the range of $6.4-43 ; 14-39 ; 140-260$; and $24200 \mathrm{mg} \cdot \mathrm{kg}^{-1}$ DW, respectively. Radulesku et al. [20] determined that the manganese, copper, zinc and iron contents in the fruiting bodies of Oyster mushrooms (Pleurotus ostreatus) were in the range of $12.40-11.50 ; 12.50-10.20 ; 41.30-37.90$; and $387.00-284.0 \mathrm{mg} \cdot \mathrm{kg}^{-1}$ DW, respectively. The same authors determined that the manganese, copper, zinc and iron contents in the fruiting bodies of Honey mushrooms (Armillaria mellea) were in the range $10.91-7.85 ; 10.43-$ 6.43; 158.2-80.5; and 745.0-432.0 mg. $\mathrm{kg}^{-1} \mathrm{DW}$, respec- 
Table 1. Mean content of chemical elements in the dried fruiting bodies (DW) of wood decaying fungi (Armillaria mellea, Lentinus edodes-Shiitake and Pleurotus ostreatus) originating from Slovakia, China and Hungary

\begin{tabular}{|c|c|c|c|c|c|c|c|c|c|c|}
\hline \multirow{2}{*}{$\begin{array}{c}\text { Chemical ele- } \\
\text { ment }\end{array}$} & \multicolumn{2}{|c|}{$\begin{array}{c}\text { Armillaria mellea } \\
\text { Slovakia }\end{array}$} & \multicolumn{2}{|c|}{$\begin{array}{c}\text { Lentinus edodes } \\
\text { China }\end{array}$} & \multicolumn{2}{|c|}{$\begin{array}{c}\text { Pleurotus ostreatus } \\
\text { Hungary }\end{array}$} & \multicolumn{2}{|c|}{$\begin{array}{c}\text { Pleurotus ostreatus } \\
\text { China }\end{array}$} & \multicolumn{2}{|c|}{$\begin{array}{c}\text { Pleurotus ostreatu } \\
\text { Slovakia }\end{array}$} \\
\hline & $\mathbf{m g} \cdot \mathbf{k g}^{-1}$ & SD & $\mathbf{m g} \cdot \mathbf{k g}^{-1}$ & SD & $\mathbf{m g} \cdot \mathbf{k g}^{-1}$ & SD & $\mathbf{m g} \cdot \mathbf{k g}^{-1}$ & SD & $\mathbf{m g} \cdot \mathbf{k g}^{-1}$ & SD \\
\hline $\begin{array}{l}\text { Boron } \\
\left(B^{11}\right)\end{array}$ & 0.615 & 0.031 & 1.078 & 0.012 & 0.323 & 0.007 & 0.563 & 0.011 & 0.426 & 0.002 \\
\hline $\begin{array}{l}\text { Sodium } \\
\left(\mathrm{Na}^{23}\right)\end{array}$ & 4.684 & 0.036 & 11.05 & 0.075 & 12.59 & 0.011 & 30.07 & 0.007 & 51.49 & 0.005 \\
\hline $\begin{array}{l}\text { Potassium } \\
\left(\mathrm{K}^{39}\right)\end{array}$ & 21009 & 0.019 & 11281 & 0.071 & 15684 & 0.077 & 13171 & 0.014 & 10588 & 0.011 \\
\hline $\begin{array}{l}\text { Calcium } \\
\left(C a^{43}\right)\end{array}$ & 34.77 & 0.013 & 35.56 & 0.010 & 73.27 & 0.015 & 126.32 & 0.005 & 58.88 & 0.024 \\
\hline $\begin{array}{l}\text { Magnesium } \\
\left(\mathrm{Mg}^{24}\right)\end{array}$ & 942.8 & 0.032 & 961.9 & 0.031 & 924.1 & 0.012 & 1028.1 & 0.018 & 956.1 & 0.021 \\
\hline $\begin{array}{l}\text { Aluminium } \\
\left(\left.A\right|^{27}\right)\end{array}$ & 145.2 & 0.013 & 69.67 & 0,005 & 14527 & 0.119 & 925.49 & 0.291 & 226.3 & 0.112 \\
\hline $\begin{array}{l}\text { Manganese } \\
\left(\mathrm{Mn}^{55}\right)\end{array}$ & 13.49 & 0.011 & 10.95 & 0.002 & 4.735 & 0.003 & 7.852 & 0.011 & 9.594 & 0.004 \\
\hline $\begin{array}{l}\text { Copper } \\
\left(\mathrm{Cu}^{63}\right)\end{array}$ & 8.729 & 0.005 & 3.542 & 0.005 & 3.428 & 0.001 & 5.517 & 0.003 & 4.653 & 0.007 \\
\hline $\begin{array}{l}\text { Zinc } \\
\left(Z n^{66}\right)\end{array}$ & 23.7 & 0,008 & 22.65 & 0,012 & 27.01 & 0,021 & 30.01 & 0.008 & 34.17 & 0.014 \\
\hline $\begin{array}{l}\text { Iron } \\
\left(\mathrm{Fe}^{57}\right)\end{array}$ & 39.39 & 0.007 & 24.16 & 0.003 & 61.83 & 0.037 & 64.64 & 0.014 & 97.03 & 0.021 \\
\hline $\begin{array}{l}\text { Cobalt } \\
\left(\mathrm{Co}^{59}\right)\end{array}$ & 0.022 & 0.001 & 0.019 & 0.001 & 0.054 & 0.003 & 0.163 & 0.002 & 0.041 & 0.001 \\
\hline $\begin{array}{l}\text { Molybdenum } \\
\left(\mathrm{Mo}^{95}\right)\end{array}$ & 0.002 & 0.001 & 0.006 & 0.001 & 0.002 & 0.001 & 0.002 & 0.001 & 0.003 & 0.001 \\
\hline $\begin{array}{l}\text { Selenium } \\
\left(\mathrm{Se}^{82}\right)\end{array}$ & 1.199 & 0.007 & 1.169 & 0.012 & 1.436 & 0.031 & 1.179 & 0.011 & 3.335 & 0.021 \\
\hline $\begin{array}{l}\text { Silver } \\
\left(\mathrm{Ag}^{107}\right)\end{array}$ & 0.748 & 0.014 & 0.102 & 0.003 & 0.052 & 0.001 & 0.274 & 0.001 & 2.503 & 0.037 \\
\hline $\begin{array}{l}\text { Mercury } \\
(\mathrm{Hg})^{202} \text { AMA }\end{array}$ & 0.074 & 0.018 & 0.011 & 0.006 & 0.021 & 0.007 & 0.097 & 0.003 & 0.799 & 0.012 \\
\hline $\begin{array}{l}\text { Cadmium } \\
\left(C d^{111}\right)\end{array}$ & 4.182 & 0.006 & 1.519 & 0.021 & 0.158 & 0.010 & 0.375 & 0.007 & 0.588 & 0.004 \\
\hline $\begin{array}{l}\text { Lead } \\
\left(\mathrm{Pb}^{208}\right)\end{array}$ & 0.681 & 0.007 & 0.631 & 0.005 & 1.026 & 0.002 & 1.978 & 0.011 & 0.703 & 0.001 \\
\hline $\begin{array}{l}\text { Arsenic } \\
\left(A s^{75}\right)\end{array}$ & 0.094 & 0.001 & 0.349 & 0.001 & 3.312 & 0.004 & 13.23 & 0.002 & 0.449 & 0.002 \\
\hline $\begin{array}{l}\text { Chrome } \\
\left(\mathrm{Cr}^{53}\right)\end{array}$ & 0.322 & 0.002 & 0.225 & 0.001 & 0.222 & 0.001 & 0.555 & 0.001 & 0.562 & 0.001 \\
\hline $\begin{array}{l}\text { Nickel } \\
\left(\mathrm{Ni}^{60}\right)\end{array}$ & 0.245 & 0.012 & 0.153 & 0.007 & 0.658 & 0.001 & 0.291 & 0.001 & 0.357 & 0.004 \\
\hline $\begin{array}{l}\text { Uranium } \\
\left(U^{238}\right)\end{array}$ & 0.022 & 0.007 & 0.019 & 0.003 & 0.059 & 0.012 & 0.073 & 0.002 & 0.026 & 0.002 \\
\hline
\end{tabular}


tively. In comparison with these published values, our results were lower. Much higher values of these elements in the fruiting bodies of Honey mushrooms (Armillaria mellea) and Oyster mushrooms (Pleurotus ostreatus) were determined by Kaya and Bag [12] and Ayaz et al. [1].

Many Slovaks like to pick up wild mushrooms in the forest and consume it by different ways. Moreover, everyone can buy both cultivated and wild mushrooms in open markets or stores. The consumption of wild and cultivated mushrooms continues to increase in many countries. This can increase transport of toxic chemical elements into humans and cause health risks to consumers.

It is necessary to know how much of mercury, cadmium, lead, chrome, arsenic and nickel are found in the fruiting bodies of wild and cultivated mushrooms. Certain countries have established statutory limits for metals in edible mushrooms. In the Slovak Republic, the limits of $0.75 \mathrm{mg} \cdot \mathrm{kg}^{-1}$ and $1.0 \mathrm{mg} \cdot \mathrm{kg}^{-1} \mathrm{FW}$ (fresh weight) have been established for mercury and cadmium in wild-growing mushrooms; whereas $0.2 \mathrm{mg} \cdot \mathrm{kg}^{-1} \mathrm{FW}$ have been established for cadmium in cultivated mushrooms. Limits of $1.0 \mathrm{mg} \cdot \mathrm{kg}^{-1}$ FW have been established for lead in wild-growing mushrooms and $0.3 \mathrm{mg} \cdot \mathrm{kg}^{-1} \mathrm{FW}$ in cultivated mushrooms. The maximum level for arsenic is $0.5 \mathrm{mg} \cdot \mathrm{kg}^{-1} \mathrm{FW}$ and for nickel is $0.5 \mathrm{mg} . \mathrm{kg}^{-1} \mathrm{FW}$ in other foods (Slovak Codex Alimentarius, Chemical contaminants) [22]. Slovak Codex Alimentarius does not have any limits for chromium in mushrooms.

The maximum level for certain contaminants in foodstuffs established by the Commission of the European Communities (Commission Regulation EC No 466/2001) [28] is set at about 0.2 and $0.3 \mathrm{mg} \cdot \mathrm{kg}^{-1}$ fresh weight for cadmium and lead, respectively, in cultivated fungi. Assuming that the dry matter content of mushrooms is $10 \%$, these same limits for dry material will be ten times higher and approach 2.0 and $3.0 \mathrm{mg} \cdot \mathrm{kg}^{-1}$ dry weight for cadmium and lead, respectively [21].

The mercury content in our samples of mushrooms was found in the range from $0.011 \mathrm{mg} \cdot \mathrm{kg}^{-1} \mathrm{DW}$ in Shiitakes (Lentinus edodes) fruiting bodies originating from China to $0.799 \mathrm{mg} \cdot \mathrm{kg}^{-1} \mathrm{DW}$ (which is equivalent $0.0799 \mathrm{mg} . \mathrm{kg}^{-1}$ FW) in fruiting bodies of Oyster mushrooms (Pleurotus ostreatus) originating from Slovakia (Table 1). The mercury content in our samples of mushrooms did not exceed the hygiene limit for fresh mushrooms.

The cadmium content in our samples of mushrooms was found in the range from 0.158 to $4.182 \mathrm{mg} \cdot \mathrm{kg}^{-1} \mathrm{DW}$. The maximum value of cadmium was accumulated in Honey mushrooms (Armillaria mellea) originating from Slovakia. The cadmium content of $4.182 \mathrm{mg} \cdot \mathrm{kg}^{-1} \mathrm{DW}\left(0.418 \mathrm{mg} \cdot \mathrm{kg}^{-1}\right.$ FW) in this mushroom did not exceed the hygiene limit of $1.0 \mathrm{mg} \cdot \mathrm{kg}^{-1}$ for fresh mushrooms (Table 1).

The lead content in our samples of mushrooms was found in the range from $0.631 \mathrm{mg} \cdot \mathrm{kg}^{-1} \mathrm{DW}$ in Shiitakes (Lentinus edodes) fruiting bodies originating from China to $1.978 \mathrm{mg} \cdot \mathrm{kg}^{-1} \mathrm{DW}$ in fruiting bodies of Oyster mushrooms (Pleurotus ostreatus), also originating from China (Table 1). Both cultivated mushrooms did not exceed the hygienic limit of $0.3 \mathrm{mg} \cdot \mathrm{kg}^{-1}$ for fresh cultivated mushrooms.

In Honey mushrooms (Armillaria mellea) fruiting bodies we found the arsenic content to be $0.094 \mathrm{mg} \cdot \mathrm{kg}^{-1} \mathrm{DW}$ and in the fruiting bodies of Oyster mushrooms (Pleurotus ostreatus) originating from China the arsenic content was $13.23 \mathrm{mg} . \mathrm{kg}^{-1} \mathrm{DW}$, which exceeded the hygiene limit of $0.5 \mathrm{mg} \cdot \mathrm{kg}^{-1} \mathrm{FW}$ for foods.

The oyster mushrooms (Pleurotus ostreatus) originating from China were probably cultivated on rice straw which is usually treated with some arsenic detergents. Arsenic accumulates in rice straw and then passes from the rice straw substrate into the fruiting bodies of Oyster mushroom (Pleurotus ostreatus).

The chromium content in our samples of mushrooms was found in the range from 0.222 to $0.562 \mathrm{mg} \cdot \mathrm{kg}^{-1} \mathrm{DW}$ (Table 1). Nearly the same chromium contents were found in the fruiting bodies of Shiitakes (Lentinus edodes) originating from China and Oyster mushrooms (Pleurotus ostreatus) originating from Hungary.

The nickel content was found in the range from 0.153 to $0.658 \mathrm{mg} . \mathrm{kg}^{-1} \mathrm{DW}$. The lowest value was determined in the fruiting bodies of Shiitakes (Lentinus edodes) originating from China and the highest nickel content was found in the fruiting bodies of Oyster mushrooms (Pleurotus ostreatus) originating from Hungary (Table 1). These values did not exceed the hygienic limit for nickel of $0.5 \mathrm{mg} \cdot \mathrm{kg}^{-1} \mathrm{FW}$ in other foods.

Relatively low levels of molybdenum (0.002-0.006 mg.kg ${ }^{-1}$ DW), cobalt (0.019-0.163 mg.kg-1 DW), and uranium $\left(0.019-0.073 \mathrm{mg} \cdot \mathrm{kg}^{-1} \mathrm{DW}\right)$ were determined in the samples of mushrooms (Table 1).

The concentrations of the accumulated chemical elements reported by some scientists vary considerably for the same mushroom species. Kalač and Svoboda [8] stated for the fruiting bodies of wild growing mushrooms, 
a mercury content ranging from $<0.5$ to $10 \mathrm{mg} \cdot \mathrm{kg}^{-1} \mathrm{DW}$. In the Honey mushrooms (Armillaria mellea) fruiting bodies, they found the mercury content lower than $0.5 \mathrm{mg} \cdot \mathrm{kg}^{-1}$ DW, and cadmium content was in the range from 2.5 to $5.0 \mathrm{mg} \cdot \mathrm{kg}^{-1} \mathrm{DW}$. Others scientists found cadmium content in the fruiting bodies of wild growing mushrooms in the range 5-50 mg. $\mathrm{kg}^{-1}$ DW. Wild growing mushrooms are good cadmium accumulators $[11,4]$. The lead content was found in the range from 1.0 to $10 \mathrm{mg} \cdot \mathrm{kg}^{-1} \mathrm{DW}$. In the Honey mushrooms (Armillaria mellea) fruiting bodies these authors found the lead content to vary from 1 to $2 \mathrm{mg} \cdot \mathrm{kg}^{-1}$ DW. In many species of mushrooms the arsenic content was lower than $0.05 \mathrm{mg} \cdot \mathrm{kg}^{-1} \mathrm{DW}$ [26].

The study of the accumulated metal elements in cultured Champignon mushrooms (Agaricus bisporus) fruiting bodies showed arsenic content in the range from 0.54 to $22.8 \mathrm{mg} \cdot \mathrm{kg}^{-1} \mathrm{DW}$ when substrate contained arsenic content 3.8 to $1000 \mathrm{mg} \cdot \mathrm{kg}^{-1} \mathrm{DW}$ [23]. Kalač and Svoboda [8] and Kalač $[10,11]$ published the chrome content in mushrooms growing in uncontaminated areas in the range from 0.1 to $2.0 \mathrm{mg} \cdot \mathrm{kg}^{-1} \mathrm{DW}$ and the nickel content in the range from 0.4 to $2.0 \mathrm{mg} \cdot \mathrm{kg}^{-1} \mathrm{DW}$.

In our study, the highest selenium content $\left(3.335 \mathrm{mg} . \mathrm{kg}^{-1}\right.$ DW) and highest silver content (2.503 mg. $\left.\mathrm{kg}^{-1} \mathrm{DW}\right)$ were found in the fruiting bodies of Oyster mushrooms (Pleurotus ostreatus) originating from Slovakia (Table 1). In the other four samples of mushrooms, the mean selenium content was $1.246 \mathrm{mg} \cdot \mathrm{kg}^{-1} \mathrm{DW}$. Our results of selenium content are in the range of the selenium content published by Kala c [10] (1-5 mg. $\left.\mathrm{kg}^{-1} \mathrm{DW}\right)$. Various species of mushrooms may accumulate different amount of selenium. In extract from the fruiting bodies of the Honey mushrooms (Armillaria mellea), the selenium content was $2.359 \mathrm{mg} \cdot \mathrm{kg}^{-1}$ and in extract from fruiting bodies of the family Boletaceae (Boletus edulis), the selenium content reached $17.0 \mathrm{mg} \cdot \mathrm{kg}^{-1}$ [18].

As it is evident from our results, edible wood decaying fungi have the ability to take up some amount of silver from the substrate. The highest silver content of $2.503 \mathrm{mg} \cdot \mathrm{kg}^{-1}$ was found in the fruiting bodies of the Oyster mushrooms (Pleurotus ostreatus) originating from Slovakia (Table 1). A considerably lower silver content of $0.748 \mathrm{mg} \cdot \mathrm{kg}^{-1}$ was found in the fruiting bodies of the Honey mushrooms (Armillaria mellea). The ability of edible wood decaying fungi to accumulate silver from the substrate decreased in the following order: Oyster mushrooms (Pleurotus ostreatus) originating from Slovakia $>$ Honey mushrooms (Armil- laria mellea) originating from Slovakia > Oyster mushroom (Pleurotus ostreatus) originating from China $>$ Shiitakes (Lentinus edodes) originating from China>and Oyster mushrooms (Pleurotus ostratus) originating from Hungary.

Some species of mushrooms may accumulate high amounts of silver from the soil contaminated with silver [2]. This provides the opportunity to obtain silver in other way than mining.

\section{CONCLUSIONS}

In general, fungi play an important role in the biosphere of soils and are intimately involved in the cycling of elements in both organic and inorganic substrates [7].

Wild growing mushrooms are also known as an unfailing source of biologically active substances used for many years in herbal medicine which is now the inspiration for finding and developing modern drugs. Mushrooms are consumed as a delicacy, and particularly for their specific aroma, taste and texture can be culinary processed in different ways.

However, it is necessary to remember that edible mushrooms can accumulate high amounts of toxic elements (mercury, cadmium, lead or arsenic). This can cause serious health problems especially in mining and metallurgical processing areas where the mushrooms grow in an environment highly contaminated by pollutants. The contamination of cultivated mushrooms with toxic elements is lower than contamination of edible wild growing mushrooms. But it also depends on the quality and composition of the substrate. If the substrate is contaminated with toxic heavy metals there is a risk of their accumulation in the fruiting bodies of mushrooms.

\section{REFERENCES}

1. Ayaz, F. A., Torun, H., Özel, A., Col, M., Duran, C., Sesli, E., Colac, A., 2011: Nutritional value of some wild edible mushrooms from the Black Sea region (Turkey). Turkish Journal of Biochemistry, 36, 385-393.

2. Borovička, J. Kotrba, P., Gryndler, M., Mihaljevič, M., Řanda, Z., Rohovec, J. et al., C. E., 2010: Bioaccumulation of silver in ectomycorrhizal and saprobic macrofungi from Pristine and polluted areas. Science of the Total Environment, 408, 2773-2744. 
3. Çağlarirmak, N., 2007: The nutrients of exotic mushrooms (Lentinula edodes and Pleurotus species) and an estimated approach to the volalite compounds. Food Chemistry, 105, 11881194.

4. Cocchi, L., Vescovi, L., Petrini L.E., Petrini, O., 2006: Heavy metals in edible mushrooms in Italy. Food Chemistry, 98, 277-284.

5. Falandysz, J., Borovička, J., 2013: Macro and trace mineral constituents and radionuclides in mushrooms: health benefits and risks. Appl. Microbiol. Biotechnol., 97, 477-501.

6. Ferreira, I. C. F. R., Barros, L., Abreu, R. M. V., 2009: Antioxidant in wild mushrooms. Current Medicinal Chemistry, 16, $1543-1560$.

7. Gadd, G. M., 2007: Geomycology: biogeochemical transformations of rock, minerals and radionuclides by fungi, bioweathering and bioremendiation. Mycol. Res., 111, 3-49.

8. Kalač, P., Svoboda, L., 2000: A review of trace element concentrations in edible mushrooms. Food Chemistry, 69, 273281.

9. Kalač, P., Svoboda, L., Havlíčková, B., 2004: Contents of cadmium and mercury in edible mushrooms. A review. Journal of Applied Biomedicine, 2, 15-20.

10. Kalač, P., 2009: Chemical composition and nutritional value of European species of wild growing mushrooms. A review. Food Chemistry, 113, 9-16.

11. Kalač, P., 2010: Trace element contents in European species of wild growing edible mushrooms: A review for the period 2000-2009. Food Chemistry, 122, 2-15.

12. Kaya, A., Bag, H., 2010: Trace element contents of edible macrofungi growing in Adiyaman, Turkey. Asian Journal of Chemistry, 22, 1515-1521.

13. Kim, Y. S., Im, J., Choi, J. N., Kang, S. S., Lee, Y. J., Lee, C.H. et al., 2010: Induction of ICM-1 by Armillaria mellea is mediated though generation of reactive oxygen species and JNK activation. Journal of Ethnopharmacology, 128, 198-205.

14. Konuk, M., Afyon, A., Yağiz. A., 2007: Minor element and heavy metal contents of wild growing and edible mushrooms from Western Black sea region of Turkey. Fresenius Environmental Bulletin PSP, 16, 1359-1362.

15. Lindequist, U., Niedermeyer, T.H.J., Jülich, W.D., 2005: The Pharmacological Potential of Mushrooms. eCAM, 2, $285-299$

16. Lung, M. Y., Chang, Y.C., 2011: Antioxidant Properties of the Edible Basidiomycete Armillaria mellea in Submerget Cultures. Int. J. Mol. Sci., 12, 6367-6384.
17. Maihara, V.A., Moura, P.L.C., Catharino, M.G.M., Moreira, E. G., Castro, L. P., Figueira, R. C. L., 2012: Cadmium determination in Lentinus edodesmushroom species. Ciencia e Technologia de Alimentos, 32, 553-557.

18. Milovanovič, I., Brčeski. I., Stajič, M., Korač, A., Vukojevič, J., Kneževič, A., 2014: Potential of Pleurotus ostreatus mycelium for selenium absorption. Scientific World Journal, 1-8, ID 681834, http://dx.doi.org/10.1155/2014/681834.

19. Muszyńska, B., Sułkowska-Ziaja, K., Wołkowska, M., Ekiert, H., 2011: Chemical, pharmacological, and biological characterization of the culinary-medicinal Honey mushroom, Armillaria mellea (Vahl) P. Kumm. (Agaricomycetideae): A review. International Journal of Medicinal Mushrooms, 13, 167-175.

20. Radulescu, C., Stihi, C., Busuioc, G., Gheboianu, A.I., Popescu, I. V., 2010: Studies concerning heavy metals bioaccumulation of wild edible mushrooms from industrial area by using spectrometric techniques. Bull. Environ. Contam. Toxicol., 84, $641-646$.

21. Rudawska, M., Leski, T., 2005: Macro- and microelement contents in fruiting bodies of wild mushrooms from the Notecka forest in west-central Poland. Food Chemistry, 92, 499-506.

22. Slovak Codex Alimentarius, Chemical contaminants, 2005: Supplement No. 1 and 2 to the third and tenth chapters of the second volume of the Codex Alimentarius: Contaminants in Food, Part A: Chemical Elements (In Slovak). XXXV, 7-1.

23. Soeroes, Cs., Kienzl, N., Ipolyi, I., Dernovics, M., Fodor, P., Kuehnelt, D., 2005: Arsenic uptake and arsenic compounds in cultivated Agaricus bisporus. Food Control, 16, 459-464.

24. Vaz, J.A., Barros, L., Martins, A., Santos-Buelga, C., Vasconcelos, M. H., Ferreira, I.C.F.R., 2011: Chemical composition of wild edible mushrooms and antioxidant properties of their water soluble polysaccharidic and ethanolic fractions. Food Chemistry, 126, 610-616.

25. Vetter, J., 1995: Boron content of edible mushrooms of Hungary. Zeitschrift für Lebensmittel Unterschung und Forschung, 201, 524-527

26. Vetter, J., 2004: Arsenic content of some edible mushroom species. European Food Research and Technology, 219, 71-74.

27. Wasser, S. P., Veis, A., 1999: Medicinal properties of substances occurring in higher Basidiomycetes mushrooms: current perspective (review). International Journal of Medicinal Mushrooms, 1, 31-36.

28. World Health Organization. Evaluation of certain of food additives and contaminants, 1989: 33rd Report of the Joint FAO/WHO expert Committee on Food Additives. Geneva WHO, WHO Technical Report Series, 776, 26-27. 
29. Xu, Y., Chen, P., Zhang, L., Ashida, H., 2012: Chain structures of glucans from Lentinus edodesand effects on NO production from RAW 264.7 macrophages. Carbohydrate Polymers, 87, 1855-1862.

30. Zhang, Y., Li, S., Wang, X., Zhang, L., Cheung, P. C. K., 2011: Advances in lentinan: Isolation, structure, chain conformation and bioactivities. Food Hydrocoloids, 25, 196-206.
31. Zhang, D., Zhang, Y., Morawska, E., Bielawski L., Krasińska, G., Drewnowska, M. et al., 2013: Trace element in Leccinum scabrum mushrooms and topsoil from Kłodzka Dale in Sudety mountains, Poland. Jounal of Mountain Science, 10, $621-627$.

Received September 6, 2016

Accepted October 7, 2016 